\begin{tabular}{|l|l|l|l|l|}
\hline Internat. Rev. Hydrobiol. & $\mathbf{9 1}$ & 2006 & 1 & $1-14$ \\
\hline
\end{tabular}

DOI: 10.1002/iroh.200510833

Verónica Ferreira* and MANuel A. S. GraçA

Departamento de Zoologia and IMAR-CIC, Universidade de Coimbra, 3004-517 Coimbra, Portugal; e-mail: veronica@ci.uc.pt

\title{
Do Invertebrate Activity and Current Velocity Affect Fungal Assemblage Structure in Leaves?
}

key words: alder leaves decomposition, aquatic hyphomycetes, artificial channels, current velocity,
shredders

\begin{abstract}
In this study we assessed the effect of current velocity and shredder presence, manipulated in artificial channels, on the structure of the fungal assemblage colonizing alder (Alnus glutinosa (L.) GAERTNER) leaves incubated in coarse and fine mesh bags. Fungal sporulation rates, cumulative conidial production and number of species of aquatic hyphomycetes were higher in leaves exposed to high rather than to low current velocity. The opposite was observed regarding Simpson's index (D) on the fungal assemblage. Some species of aquatic hyphomycetes were consistently stimulated in high current channels. No effect of shredders or of mesh type was observed.
\end{abstract}

\section{Introduction}

In forested low order streams, the primary energy source for aquatic communities is allochthonous organic matter provided by trees in the riparian zone (VANNOTE et al., 1980), mostly in the form of leaves (Pozo et al., 1997). Decomposition is a vital ecological process, mostly carried out by fungi and invertebrate decomposers (GESSNER et al., 1999; HIEBER and GESSNER, 2002). Fungal activity causes leaf breakdown, and appreciable amount of detrital carbon is converted into mycelial and conidial biomass (GESSNER and CHAUvET, 1994). Invertebrates, in particular leaf-shredding invertebrates (= shredders), have also been shown to be important decomposers (e.g. CufFNEY et al., 1990; STEWART, 1992). However, shredders seem to depend strongly on microbial colonization of leaves (GRAÇA et al., 2001). Shredders may benefit from fungal colonization because the accumulation of fungal biomass enhances the litter quality (conditioning) as (1) fungal enzymes aid in digestion of leaf tissues and (2) fungi are food for shredders (BÄRLOCHER and KENDRICK, 1975; ARSUFFI and SubERKROPP, 1988). Shredders can discriminate between leaf patches colonized by different fungal species and at different degrees of conditioning (ARSUFFI and SUBERKROPP, 1985, $1986,1989)$. Thus, by feeding selectively on certain fungal species or in leaf areas rich in fungal cells, shredders might directly influence the fungal assemblage structure. This can be assessed by comparing decomposing leaves (a) between bags protected and unprotected from shredders or (b) between streams with (natural condition) and without invertebrates (by excluding them with insecticide) (SUBERKROPP, 2003).

* Corresponding author 
However, results generated so far are inconclusive. Using the first approach, BÄRLOCHER observed that feeding activity by invertebrates lowered fungal species richness (BÄRLOCHER, 1980) or fungal sporulation rates (BÄRLOCHER, 1982) in oak leaves and larch needles incubated in coarse mesh bags, when compared with fine mesh bags. This was attributed to shredders likely acting as competitors through promoting fast mass loss in coarse mesh bags, thus reducing the space available for late colonizer species (BÄRLOCHER, 1980) or to the direct consumption of early colonizing aquatic hyphomycetes by the shredder Gammarus fossarum (BÄRLOCHER, 1982). On the other hand, ROSSI (1985) found a higher diversity of aquatic fungi, and SABETTA et al. (2000) found higher respiration rates and numbers of species of aquatic fungi in leaves unprotected from invertebrates than in leaves protected from invertebrates. This could be explained by damage of the leaf epidermis by the invertebrate activities and thus facilitating fungal colonization and establishment (SUBERKROPP and KLUG, 1976). GRAÇA et al. (2002) also found that invertebrate shredding could stimulate fungal growth on decaying litter, when grazing intensity was not high. But again, HowE and SUBERKROPP (1994) found no significant differences in fungal species richness, microbial respiration or biomass in poplar leaves protected and unprotected from the consumer Lirceus sp. Only sporulation rates were significantly different between bag types, but this was attributed to a reduction in water flow in fine mesh bags. Using the second approach, SUBERKROPP and WALLACE (1992) compared the fungal assemblage in leaves incubated in an insecticide treated stream and two untreated reference streams and found no significant differences in fungal species composition between treated and untreated streams, although in the treated stream fungi sporulated at higher frequencies.

Current velocity can also be an important factor regulating the fungal assemblage structure. It has been shown that aquatic hyphomycetes colonize preferentially oxygen rich waters (CHAuvet, 1992) and turbulence stimulates spore release. Thus, the use of fine mesh bags to assess the fungal assemblage structure can be questionable since a fine mesh might unnaturally reduce physical leaf fragmentation and change water flow patterns (SUBERKROPP, 2003). This may in turn lead to a reduction in species diversity and/or sporulation rates (HOWE and SUBERKROPP, 1994).

In this study we assessed the effect of current velocity and shredder presence, manipulated in artificial channels, in the structure of the fungal assemblage colonizing alder (Alnus glutinosa (L.) GAERTNER) leaves incubated in coarse and fine mesh bags. This is part of a wider experiment in which we studied the effect of current and shredder presence on litter decomposition. Manipulation allowed us to compare fungal assemblage structure and sporulation rates (1) between coarse and fine mesh bags, assessing in this way the effect of the mesh size, and (2) between coarse mesh bags placed in channels differing in current velocity and invertebrate density, assessing in this way the effect of both current velocity and invertebrate activity. Fungal sporulation rates were expected to be higher in leaves incubated in coarse mesh bags at higher current velocity and in the absence of shredders.

\section{Methods}

\subsection{Alder Leaves in Artificial Channels}

Alder (Alnus glutinosa (L.) GAERTNER) leaves were used as a decomposition substrate. Leaves were collected from the same group of trees at Varandas do Ceira (Portugal, N 40 $10^{\prime} 20^{\prime \prime}$; W $8^{\circ} 18^{\prime} 10^{\prime \prime}$ ) just after abscission (4-12 November, 2002). They were air dried and stored until needed. Batches of $0.74-1.00 \mathrm{~g}$ (mean $=0.86 \mathrm{~g}$ ) of air-dry leaves were rehydratated and placed in fine mesh (FM; $10 \times 15 \mathrm{~cm}, 0.5 \mathrm{~mm}$ mesh size; to prevent invertebrate access to leaves) and coarse mesh (CM; $10 \times 15 \mathrm{~cm}, 10 \mathrm{~mm}$ mesh size; to allow invertebrate access to leaves) bags. Six bags were set apart to determine the initial dry mass - ash free dry mass (AFDM) conversion factor. Five fine mesh and five 
$1 \mathbf{a}$

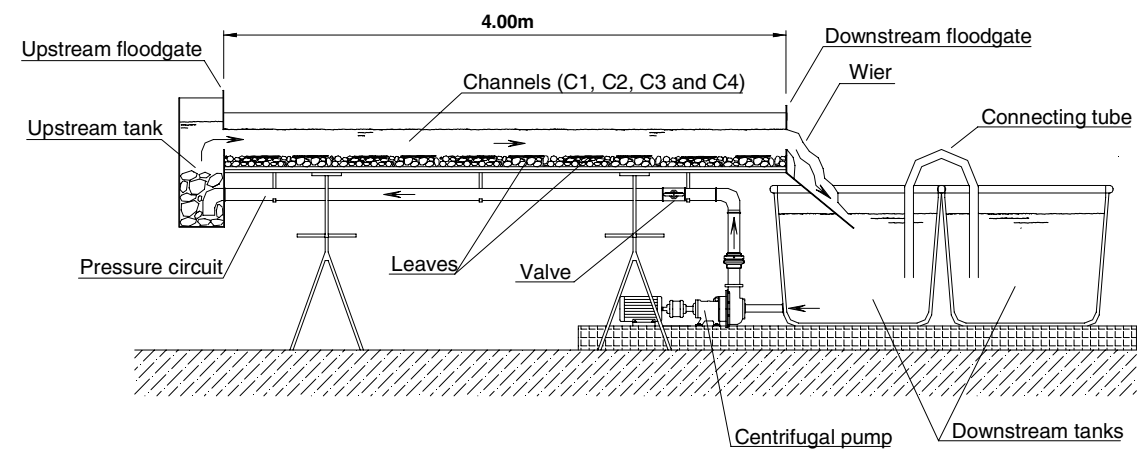

$1 \mathrm{~b}$

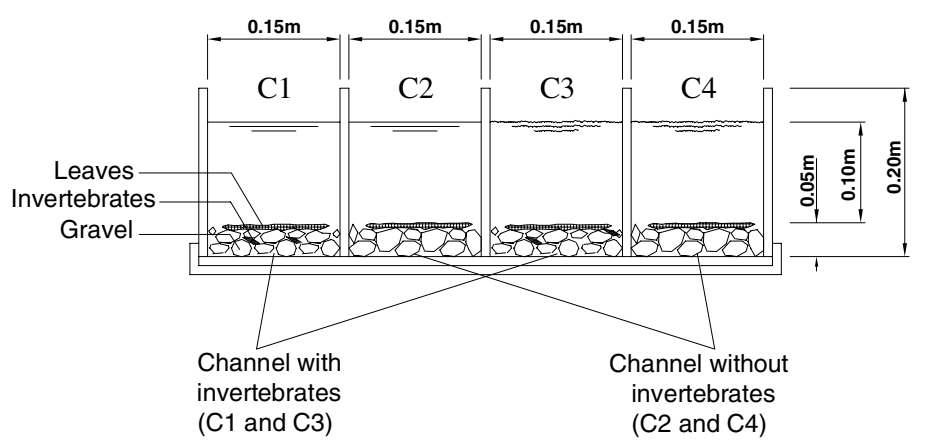

Figure 1. Scheme of the flume used in the laboratory experiments in lateral (a) and cross-section (b) views. The arrows show the direction of flow in the hydraulic circuit. Channels $\mathrm{C} 1$ and $\mathrm{C} 2$ had low current velocity while channels C3 and C4 had high current velocity. Channels C1 and C3 had shredders.

coarse mesh bags were placed in each of four contiguous artificial channels where current velocity and shredder presence (Sericostoma sp.) were manipulated (Fig. 1; for more details on the channels see FERREIRA et al., in press).

As an inoculum of aquatic fungi, conditioned leaves (approximately $20 \mathrm{~g}$ ) were collected from a local stream (S. João stream, Lousã, Central Portugal, N 40 $05^{\prime} 59^{\prime \prime}$, W $8^{\circ} 14^{\prime} 02^{\prime \prime}$ ) and placed in the upstream tank that delivered water to the channels (Fig. 1). Water $\left(1 \mathrm{~m}^{3}\right)$ was also collected from the same stream. Current velocity (measured by the volumetric method) was set to match the maximum measured in zones of the stream where there was organic matter accumulation $\left(0.2 \mathrm{~m} \mathrm{~s}^{-1}\right.$; channels $\mathrm{C} 3$ and $\left.\mathrm{C} 4\right)$ and to a low value $\left(0.05 \mathrm{~m} \mathrm{~s}^{-1}\right.$; channels $\mathrm{C} 1$ and $\left.\mathrm{C} 2\right)$.

In one low (C1) and one high (C3) current velocity channels, 100 individuals of the shredder Sericostoma sp. (Trichoptera: Sericostomatidae) were added so as to match densities observed in the field. The animals were collected from two streams (S. João stream, Lousã and Castelões stream, Caramulo) and they were in the laboratory for at least one week before being placed in the channels.

After 7, 14, 21, and 28 days in water, one fine mesh and one coarse mesh bag were retrieved from each channel. To maintain the same amount of organic matter in the channels, each retrieved bag was replaced with a new one. To maintain the density of invertebrates in the channels, all the individuals that were attached to the leaves were removed and placed again in the same channel and new larvae replaced all the pupae and empty cases. Physico-chemical parameters of the water were also monitored including pH (JENWAY 3310, Essex, U.K.), conductivity and temperature (WTW LF 330, Weilheim, 
Germany). Water was collected, in acid washed plastic bottles, and alkalinity was determined by titration to an end point of 4.5 (APHA, 1995), $\mathrm{NO}_{3}-\mathrm{N}$ was determined by ion chromatography (Dionex DX-120, Sunnyvale, CA) and $\mathrm{PO}_{4}-\mathrm{P}$ was determined by the ascorbic acid method (APHA, 1995).

\subsection{Fungal Sporulation and Mass Loss}

Leaves retrieved from the artificial channels were rinsed with distilled water and 5 leaf disks from each bag were cut out with a cork borer (12 mm diameter). Leaf disks were incubated in $100 \mathrm{~mL}$ Erlenmeyer flasks with $25 \mathrm{~mL}$ of filtered channels water (glass fiber filter, Millipore, APFF) on an orbital shaker (100 rpm) for $48 \mathrm{~h}$ at $15^{\circ} \mathrm{C}$ to induce sporulation by aquatic hyphomycetes. The conidia suspensions were fixed with $2 \mathrm{~mL}$ of $37 \%$ formalin for later counting and identification. When preparing slides, $100 \mu \mathrm{L}$ of $0.5 \%$ Triton X-100 solution were added to the suspension to ensure a uniform distribution of conidia, stirred and an aliquot of the suspension was filtered (Millipore SMWP, pore size $5 \mu \mathrm{m})$. Filters were stained with $0.05 \%$ cotton blue in lactic acid, and spores were identified and counted with a compound microscope at $200 \times$.

Leaf remainings (including leaf disks after sporulation) were placed in an oven at $70{ }^{\circ} \mathrm{C}$ for $72 \mathrm{~h}$, weighed, ashed at $550{ }^{\circ} \mathrm{C}$ for $4 \mathrm{~h}$ and reweighed to calculate remaining AFDM. The experiment was repeated three times $\left(1^{\text {st }}\right.$ run on February, $2^{\text {nd }}$ on March and $3^{\text {rd }}$ on April, 2003), to generate replicates. Between each run, water, conditioned leaves and animals were changed and stones, sand and channels were clean.

\subsection{Statistical Analysis}

Comparisons of water parameters among the three experimental runs were made by 1-way ANOVA. Percentages of AFDM remaining (arcsine square root transformed) of alder leaves after 28 days of incubation in the channels was compared among mesh types and channels using a 3-way ANOVA with mesh type, current velocity and shredders as categorical variables.

Sporulation rates (conidia $\mathrm{mg}^{-1} \mathrm{AFDM} \mathrm{day}^{-1}$ ) and number of species of aquatic hyphomycetes on alder leaves along time were compared among mesh types and channels using a 4-way ANOVA with mesh type, current velocity, shredders and time as categorical variables. The number of species colonizing leaves on day 7 was also compared among mesh types and channels using a 3-way ANOVA with mesh type, current velocity and shredders as categorical variables. Cumulative conidial production at each sampling date was calculated by summing up values of daily production at each sampling date and linearly approximated values for each day between sampling dates. Comparisons among slopes were done by 4-way ANCOVA with mesh type, current velocity and shredders as categorical variables and time as continuous variable.

Since different fungal inocula were used in the three runs, individual fungal species responses to current velocity and shredder activity were compared in the 3 runs individually and a species was considered to be sensitive to current velocity or shredder activity when it responded in the same way in all three runs. Differences between treatments were assessed by paired $t$ test.

Simpson's index,

$$
\mathrm{D}=\sum_{\mathrm{i}=1}^{\mathrm{S}} \frac{\mathrm{n}_{\mathrm{i}}\left(\mathrm{n}_{\mathrm{i}}-1\right)}{\mathrm{N}(\mathrm{N}-1)}
$$

where $n_{i}$ is the number of individuals of species $i, N$ is the total number of individuals and $S$ the total number of species, was also calculated as a measure of heterogeneity and gives the probability of two individuals chosen at random and independently from the population belonging to the same species (WASHINGTON, 1984). Comparisons among mesh types and channels were done using a 4-way ANOVA with mesh type, current velocity, shredders and time as categorical variables. Statistical analyses were done with STATISTICA 6 software. 
3. Results

\subsection{Water Parameters, Shredders and Mass Loss}

Conditions in all measured water parameters (except current velocity) were not statistically different among the three experimental runs (1-way ANOVA, P > 0.062; Table 1). In spite of higher current velocities in the $1^{\text {st }}$ run $(1$-way ANOVA, $\mathrm{P}<0.001)$, the ratio between the high and the low current velocity channels was always 5 (Table 1).

Table 1. Mean (SE) chemical and physical parameters of water in channels, in the 3 runs ( $\mathrm{n}=6$, except in $*$, where only one measurement was made).

\begin{tabular}{|c|c|c|c|}
\hline & $1^{\text {st }}$ run & $2^{\text {nd }}$ run & $3^{\text {rd }}$ run \\
\hline pH & $7.2(0.1)$ & $7.0(*)$ & $7.1(*)$ \\
\hline Alkalinity $\left(\mathrm{mg} \mathrm{CaCO}_{3} \mathrm{~L}^{-1}\right)$ & $12.9(1.4)$ & $11.4(*)$ & - \\
\hline Conductivity $\left(\mu \mathrm{S} \mathrm{cm} \mathrm{cm}^{-1}\right)$ & $59.1(4.6)$ & $58.4(6.1)$ & $62.4(6.4)$ \\
\hline $\mathrm{NO}_{3}-\mathrm{N}\left(\mu \mathrm{g} \mathrm{L^{-1 }}\right)$ & $712.2(154.8)$ & $1130.0(314.1)$ & $1521.5(412.5)$ \\
\hline $\mathbf{P O}_{4}-\mathrm{P}\left(\mu \mathrm{g} \mathrm{L}^{-1}\right)$ & $4.2(1.2)$ & $6.5(1.6)$ & $2.3(0.6)$ \\
\hline Temperature $\left({ }^{\circ} \mathbf{C}\right)$ & $22.4(0.2)$ & $22.9(0.2)$ & $23.2(0.2)$ \\
\hline \multicolumn{4}{|l|}{ Current Velocity $\left(\mathrm{m} \mathrm{s}^{-1}\right)$} \\
\hline Channel C1 & $0.05(0.0004)$ & $0.04(0.0007)$ & $0.04(0.0005)$ \\
\hline Channel C2 & $0.05(0.0004)$ & $0.04(0.0005)$ & $0.04(0.0007)$ \\
\hline Channel C3 & $0.25(0.0006)$ & $0.17(0.0026)$ & $0.17(0.0021)$ \\
\hline Channel C4 & $0.25(0.0006)$ & $0.17(0.0027)$ & $0.17(0.0016)$ \\
\hline
\end{tabular}

During the experiment some sericostomatids were lost due to pupation and, in spite of larvae replacement, by the end of each run the difference in the number of shredders between $\mathrm{C} 1$ and $\mathrm{C} 3$ was $1-16 \%$.

Mass loss was significantly higher for alder leaves incubated in channels with shredders (C1 and $\mathrm{C} 3)$ than in channels without shredders (C2 and C4; 3-way ANOVA, P = 0.004) but only in coarse mesh bags ( 3 -way ANOVA, $\mathrm{P}=0.002$ ) (Table 2 and 3). No significant differences were found between bags exposed to different current velocities (3-way ANOVA, $\mathrm{P}=0.186$; Table 2 and 3). For more details on the effect of current velocity and inveterate activity on decomposition of alder leaves in artificial channels and stream conditions see FERREIRA et al. (in press).

Table 2. Remaining AFDM (\%) of alder leaves incubated in coarse mesh (CM) and fine mesh (FM) bags in channels 1 (C1), 2 (C2), $3(\mathrm{C} 3)$ and $4(\mathrm{C} 4)$ for 28 days, in the 3 runs.

\begin{tabular}{lccccc}
\hline & Current & Shredders & $\mathbf{1}^{\text {st }}$ run & $\mathbf{2}^{\text {nd }}$ run & $\mathbf{3}^{\text {rd }}$ run \\
\hline CM-C1 & Low & Yes & 32 & 33 & 41 \\
FM-C1 & Low & Yes & 53 & 76 & 60 \\
CM-C2 & Low & No & 59 & 64 & 64 \\
FM-C2 & Low & No & 62 & 61 & 60 \\
CM-C3 & High & Yes & 6 & 36 & 38 \\
FM-C3 & High & Yes & 55 & 59 & 62 \\
CM-C4 & High & No & 62 & 53 & 57 \\
FM-C4 & High & No & 57 & 62 & 55 \\
\hline
\end{tabular}


Table 3. Results from the 3-way ANOVA (mesh type, current velocity and shredders as categorical variables) on remaining AFDM of alder leaves incubated in the artificial channels for 28 days.

\begin{tabular}{lrrrrc}
\hline & \multicolumn{1}{c}{ SS } & df & \multicolumn{1}{c}{ MS } & F ratio & p \\
\hline Intercept & 404.413 & 1 & 404.413 & 1839.096 & 0.000 \\
Mesh type & 2.762 & 1 & 2.762 & 12.562 & 0.003 \\
Velocity & 0.420 & 1 & 0.420 & 1.910 & 0.186 \\
Shredders & 2.511 & 1 & 2.511 & 11.417 & 0.004 \\
Mesh type*Velocity & 0.108 & 1 & 0.108 & 0.490 & 0.500 \\
Mesh type*Shredders & 2.853 & 1 & 2.853 & 12.973 & 0.002 \\
Velocity*Shredders & 0.079 & 1 & 0.079 & 0.357 & 0.558 \\
Mesh type*Velocity*Shredders & 0.056 & 1 & 0.056 & 0.256 & 0.620 \\
Error & 3.518 & 16 & 0.220 & & \\
\hline
\end{tabular}

With shredders
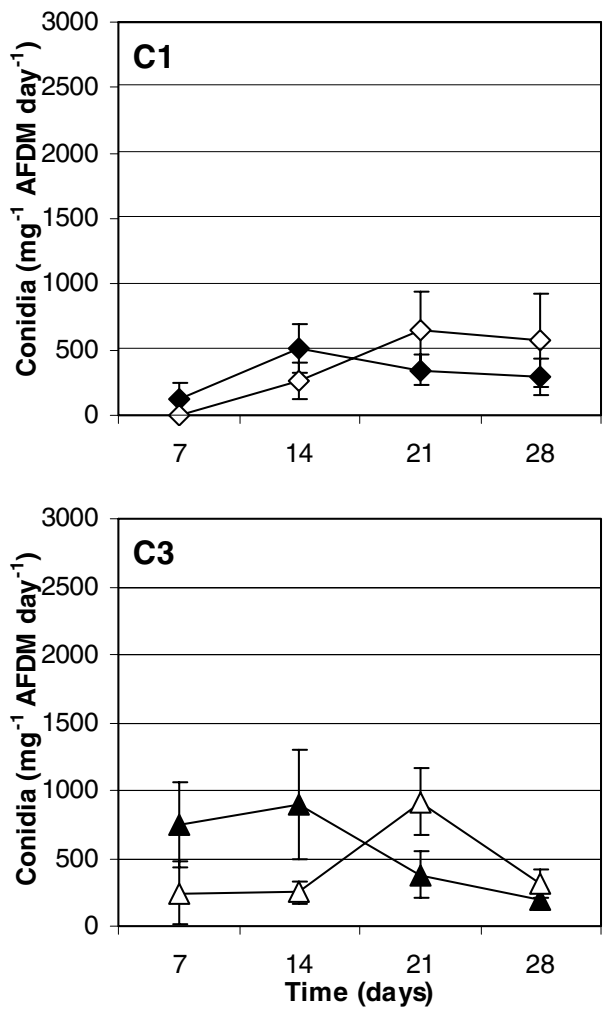

Without shredders
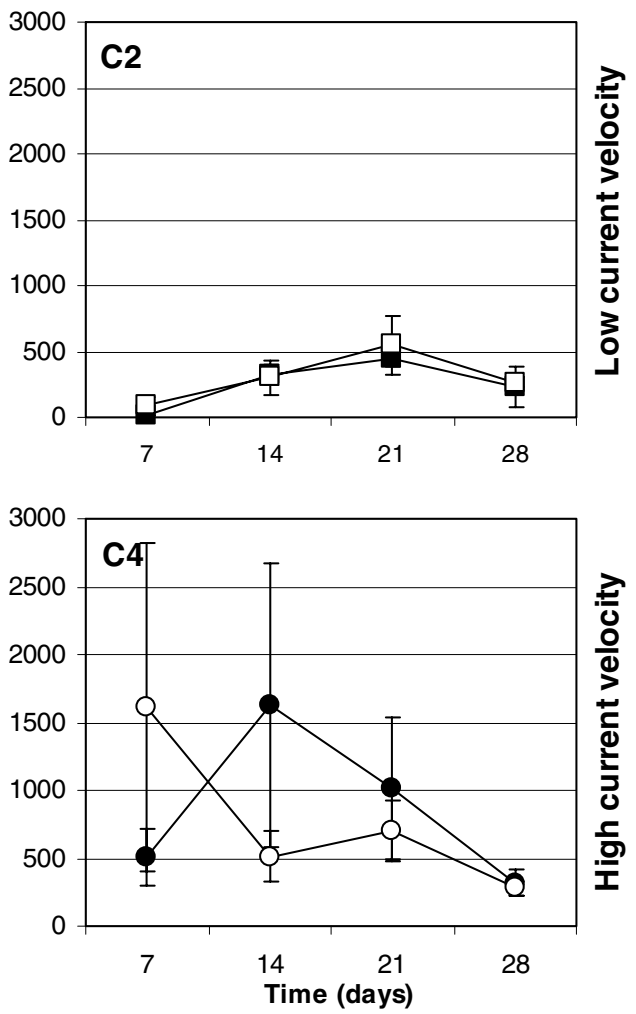

Figure 2. Sporulation rate (mean $\pm \mathrm{SE}$ ) by aquatic hyphomycetes colonizing alder leaves incubated in coarse mesh (solid symbols) and fine mesh (open symbols) bags in channels C1, C2, C3 and C4. 


\subsection{Fungal Assemblage}

Twenty samples (the majority from day 7) produced less than 100 conidia $\mathrm{mg}^{-1}$ AFDM day $^{-1}$ and only 10 samples produced more than 1000 conidia $\mathrm{mg}^{-1}$ AFDM day ${ }^{-1}$. A maximum of 4025 conidia $\mathrm{mg}^{-1}$ AFDM day ${ }^{-1}$ was recorded from fine mesh bags in channel 4 (high current, no shredder) on day 7 from the $2^{\text {nd }}$ run. In general, sporulation pattern was similar for most bag types. The sporulation rate increased until days 14 or 21 , decreasing thereafter (Fig. 2). The high variability (SE bars) found for fine and coarse mesh bags in C4 (high current, no shredder) on days 7 and 14, respectively, was due to the high sporulation these bags presented on the $2^{\text {nd }}$ run. Sporulation rate was higher for leaves in high than in low current channels (4-way ANOVA, P $<0.001$ ) but no difference was found between channels with and without shredders (4-way ANOVA, $\mathrm{P}=0.265$ ) (Table 4).

Cumulative conidial production was also significantly higher in leaves exposed in high than in low current channels (4-way ANCOVA, P $<0.001$; Fig. 3 and Table 5). In channel C3 (high current, with shredders) there was higher conidial production in coarse than in fine mesh bags (4-way ANCOVA, $\mathrm{P}=0.023$ ), however, considering the 4 channels, there was no effect of shredders or mesh type in the conidial production (4-way ANCOVA, P > 0.337) (Table 5). The higher values found for leaves in C4 (high current velocity, no shredders) were, to a great extent, due to the high sporulation registered in the $2^{\text {nd }}$ run.

A minimum of 2 and a maximum of 11 species of aquatic hyphomicetes were identified from samples retrieved from the channels. The dynamics of species colonization was similar to sporulation, with a peak in number of species by day 14-21 (Fig. 4). No significant differences were found among mesh types (4-way ANOVA, $\mathrm{P}=0.726$; Table 6). Leaves incubated in high current channels had a greater number of species than leaves incubated in low current channels (4-way ANOVA, $\mathrm{P}=0.011$ ) but again no difference was found between channels with and without shredders (4-way ANOVA, $P=0.985)$ (Table 6). No significant differences were found in the number of fungal species colonizing leaves on day 7

Table 4. Results from the 4-way ANOVA (mesh type, current, velocity, shredders and time as categorical variables) on the sporulation by aquatic hyphomycetes colonizing alder leaves incubated in artificial channels.

\begin{tabular}{lrrrrc}
\hline & \multicolumn{1}{c}{ SS } & df & \multicolumn{1}{c}{ MS } & F ratio & p \\
\hline Intercept & 538.088 & 1 & 538.088 & 2399.110 & 0.000 \\
(1) Mesh type & 0.019 & 1 & 0.019 & 0.083 & 0.774 \\
(2) Velocity & 4.394 & 1 & 4.394 & 19.592 & 0.000 \\
(3) Shredders & 0.284 & 1 & 0.284 & 1.265 & 0.265 \\
(4) Time & 9.527 & 3 & 3.176 & 14.159 & 0.000 \\
Mesh type*Velocity & 0.120 & 1 & 0.120 & 0.537 & 0.466 \\
Mesh type*Shredders & 0.618 & 1 & 0.618 & 2.756 & 0.102 \\
Velocity*Shredders & 0.501 & 1 & 0.501 & 2.235 & 0.140 \\
Mesh type*Time & 1.129 & 3 & 0.376 & 1.678 & 0.181 \\
Velocity*Time & 5.851 & 3 & 1.950 & 8.696 & 0.000 \\
Shredders*Time & 0.325 & 3 & 0.108 & 0.482 & 0.696 \\
Mesh type*Velocity*Shredders & 0.158 & 1 & 0.158 & 0.707 & 0.404 \\
Mesh type*Velocity*Time & 0.108 & 3 & 0.036 & 0.161 & 0.922 \\
Mesh type*Shredder*Time & 3.149 & 3 & 1.050 & 4.680 & 0.005 \\
Velocity*Shredders*Time & 0.149 & 3 & 0.050 & 0.221 & 0.881 \\
$1 * 2 * 3 * 4$ & 0.010 & 3 & 0.003 & 0.015 & 0.997 \\
Error & 14.354 & 64 & 0.224 & & \\
\hline
\end{tabular}




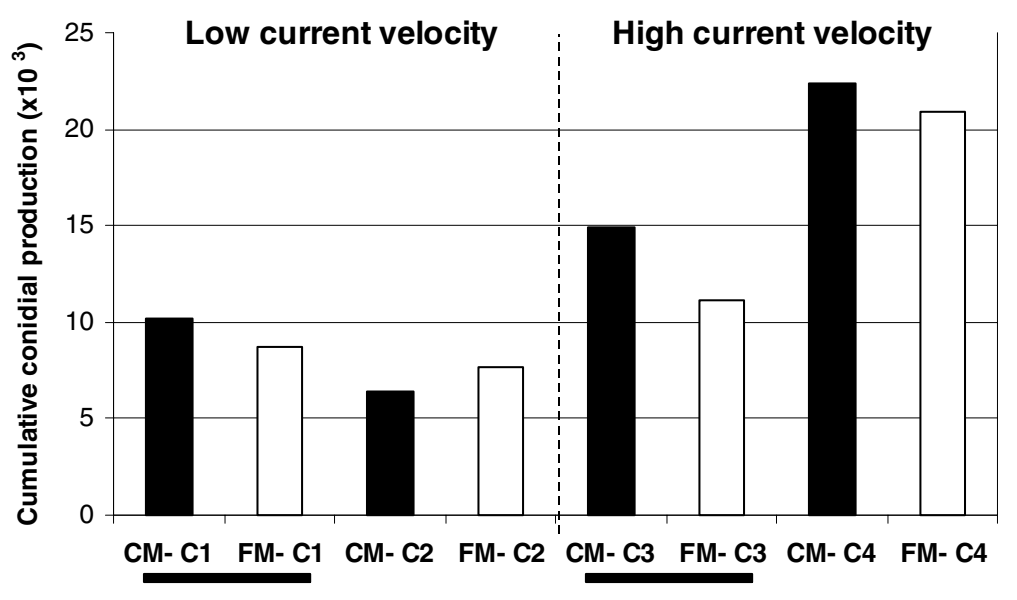

Figure 3. Cumulative conidia production by aquatic hyphomycetes colonizing alder leaves incubated in coarse mesh $(\mathrm{CM})$ and fine mesh $(\mathrm{FM})$ bags in channels $\mathrm{C} 1, \mathrm{C} 2, \mathrm{C} 3$ and $\mathrm{C} 4$ after 28 days. Horizontal solid bars indicate shredder presence.

that could be attributed to either mesh type, current or shredders (3-way ANOVA, $\mathrm{P}>0.208$ ).

There was no consistent difference in species identity among mesh types and channels for the 3 runs (data not shown). The same was observed for species abundance; except for Tetrachaetum elegans, Tricladium chaetocladium and Triscelophorus monosporus, which were more abundant in high current channels, being the reverse true for Lunulospora curvula (paired t test, $\mathrm{P}<0.003$; Table 7). In the $1^{\text {st }}$ run, the dominant species were Triscelophorus acuminatus (maximum of $88 \%$ of spores produced per sample), L. curvula (maximum of $82 \%$ ) and T. elegans (maximum of $58 \%$ ); in the $2^{\text {nd }}$ run, the dominant species were T. chaetocladium (maximum of $71 \%$ ), T. elegans (maximum of $51 \%$ ) and L. curvula (maximum of $62 \%$ ); and in the $3^{\text {rd }}$ run, the dominant species were L. curvula (maximum of $96 \%$ ) and Anguillospora filiformis (maximum of 52\%).

Table 5. Results from the 4-way ANCOVA (mesh type, current velocity and shredders as categorical variables and time as continuous variable) on the cumulative conidial production by aquatic hyphomycetes colonizing alder leaves incubated in artificial channels.

\begin{tabular}{lcrc}
\hline & df & F ratio & p \\
\hline Intercept & 1 & 454.060 & 0.000 \\
Time(days) & 1 & 50.468 & 0.000 \\
Mesh type & 1 & 0.725 & 0.394 \\
Velocity & 1 & 25.511 & 0.000 \\
Shredders & 1 & 0.924 & 0.337 \\
Mesh type*Velocity & 1 & 0.000 & 0.987 \\
Mesh type*Shredders & 1 & 5.179 & 0.023 \\
Velocity*Shredders & 1 & 1.520 & 0.218 \\
Mesh type*Velocity*Shredders & 1 & 0.376 & 0.540 \\
\hline
\end{tabular}


With shredders
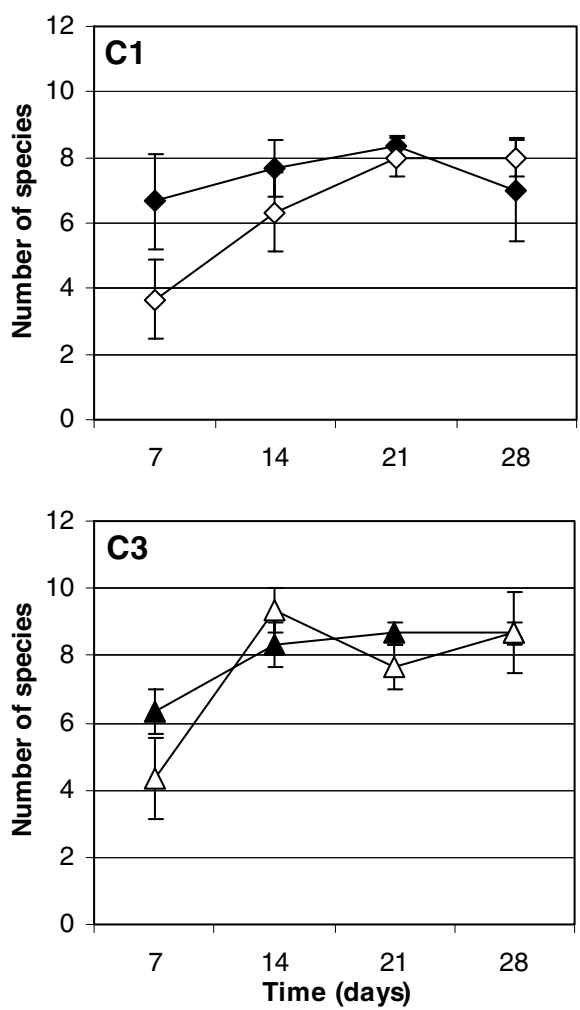

Without shredders
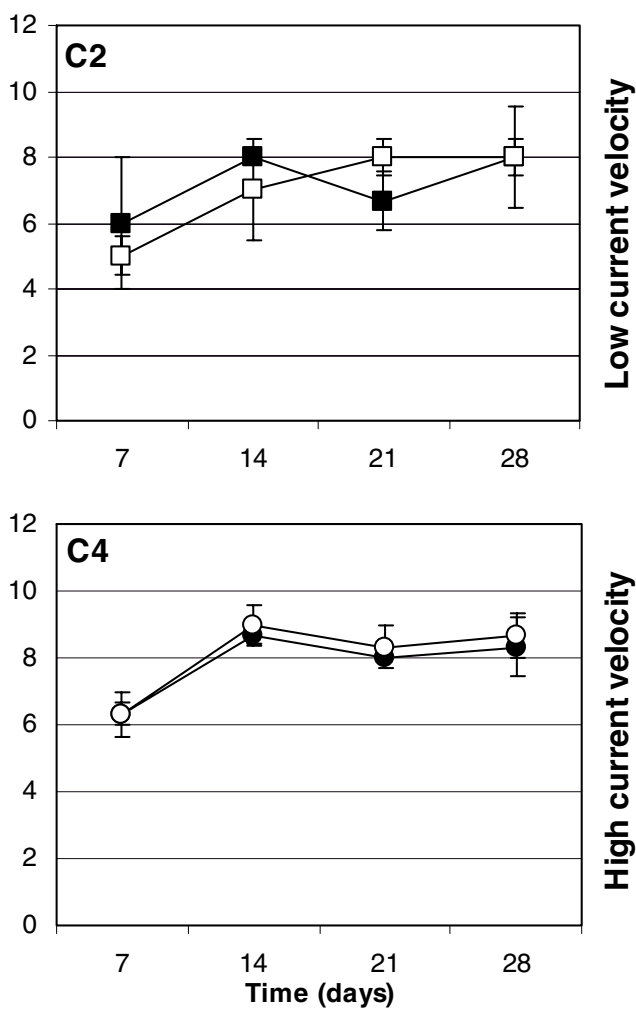

Figure 4. Number of species (mean $\pm \mathrm{SE}$ ) of aquatic hyphomycetes colonizing alder leaves incubated in coarse mesh (solid symbols) and fine mesh (open symbols) bags in channels C1, C2, C3 and C4.

Simpson's index was in general low $(<0.55$; Fig. 5), which indicates that the fungal assemblage on leaves was not clearly dominated by a single species. However, there was a current velocity effect with the fungal assemblage in alder leaves incubated in high current rather than low current channels having lower values (4-way ANOVA, $\mathrm{P}=0.001$; Table 8).

\section{Discussion}

The absence of significant differences in fungal sporulation rates, cumulative conidial production, number of fungal species and Simpson's index (heterogeneity of fungal assemblage) that could be attributed to mesh size demonstrated that there was probably no alteration of the physical environment surrounding leaves inside fine mesh bags $(0.5 \mathrm{~mm}$ mesh) when compared with coarse mesh bags (10 $\mathrm{mm}$ mesh). This was supported by the absence of significant differences in mass loss of alder leaves between coarse mesh and fine mesh bags in channels without shredders. This was opposite to what was observed by Howe and SubERKROPP (1994), who reported higher fungal sporulation in coarse mesh than in fine 
Table 6. Results from the 4-way ANOVA (mesh type, current velocity, shredders and time as categorical variables) on the number of species of aquatic hyphomycetes colonizing alder leaves incubated in artificial channels.

\begin{tabular}{lrrrrc}
\hline & SS & df & MS & F ratio & p \\
\hline Intercept & 78.563 & 1 & 78.563 & 5029.221 & 0.000 \\
(1) Mesh type & 0.002 & 1 & 0.002 & 0.124 & 0.726 \\
(2) Velocity & 0.106 & 1 & 0.106 & 6.789 & 0.011 \\
(3) Shredders & 0.000 & 1 & 0.000 & 0.000 & 0.985 \\
(4) Time & 0.623 & 3 & 0.208 & 13.297 & 0.000 \\
Mesh type*Velocity & 0.001 & 1 & 0.001 & 0.067 & 0.796 \\
Mesh type*Shredders & 0.048 & 1 & 0.048 & 3.045 & 0.086 \\
Velocity*Shredders & 0.010 & 1 & 0.010 & 0.609 & 0.438 \\
Mesh type*Time & 0.014 & 3 & 0.005 & 0.302 & 0.824 \\
Velocity*Time & 0.030 & 3 & 0.010 & 0.632 & 0.597 \\
Shredders*Time & 0.005 & 3 & 0.002 & 0.108 & 0.955 \\
Mesh type*Velocity*Shredders & 0.007 & 1 & 0.007 & 0.450 & 0.505 \\
Mesh type*Velocity*Time & 0.029 & 3 & 0.010 & 0.626 & 0.601 \\
Mesh type*Shredders*Time & 0.103 & 3 & 0.034 & 2.196 & 0.097 \\
Velocity*Shredders*Time & 0.042 & 3 & 0.014 & 0.897 & 0.448 \\
$1 * 2 * 3 * 4$ & 0.027 & 3 & 0.009 & 0.571 & 0.636 \\
Error & 1.000 & 64 & 0.016 & & \\
\hline
\end{tabular}

mesh bags as a result of clogging of fine mesh bags by fine particles. The difference of the effect of mesh size on the fungal assemblage between our study and the one by HowE and SuBERKROPP (1994) may have been due to the smaller fine mesh $(0.36 \mathrm{~mm})$ used by Howe and SUBERKROPP and to the fact that their study was performed in a stream whereas our study was perform in artificial channels where suspended sediments were absent. BÄRLOCHER

Table 7. Mean relative abundance (\%) of aquatic hyphomycete conidia colonizing alder leaves in low and high current velocity channels, in the 3 runs. Shaded species presented a consistent response to current velocity. + , mean relative abundance $<0.1 \%$.

\begin{tabular}{|c|c|c|c|c|c|c|}
\hline \multirow[t]{2}{*}{ Species } & \multicolumn{2}{|c|}{$1^{\text {st }}$ run } & \multicolumn{2}{|c|}{$2^{\text {nd }}$ run } & \multicolumn{2}{|c|}{$3^{\text {rd }}$ run } \\
\hline & Low & High & Low & High & Low & High \\
\hline Alatospora acuminata INGOLD & 0.7 & 1.8 & 0.5 & 0.5 & 0.1 & 0.3 \\
\hline Anguillospora filiformis GREATHEAD & 2.0 & 3.6 & 12.3 & 7.3 & 24.1 & 27.0 \\
\hline Anguillospora longissima (SACC. et SYD.) INGOLD & & & + & & & \\
\hline Articulospora tetracladia INGOLD & 20.1 & 1.9 & 0.2 & 0.6 & & 0.1 \\
\hline Clavariopsis aquatica DE WILD & & + & 0.4 & 0.9 & 0.1 & 0.3 \\
\hline Heliscus ludgunensis SACC. et THÉRRY & & & + & 0.1 & + & \\
\hline Lemonniera aquatica DE WILD. & 0.2 & & & & & \\
\hline Lunulospora curvula INGOLD & 20.4 & 16.7 & 22.7 & 2.8 & 48.8 & 13.2 \\
\hline Tetrachaetum elegans INGOLD & 16.3 & 19.8 & 13.1 & 19.7 & 4.3 & 9.9 \\
\hline Tricladium chaetocladium INGOLD & 1.4 & 3.4 & 24.6 & 41.2 & 6.5 & 16.6 \\
\hline Triscelophorus acuminatus NAWAWI & 29.7 & 37.5 & 8.7 & 6.3 & 4.6 & 2.9 \\
\hline Triscelophorus monosporus INGOLD & 2.2 & 9.0 & 5.4 & 6.1 & 4.3 & 12.1 \\
\hline Unidentified tetraradiate* & 0.1 & 0.3 & 1.8 & 7.4 & 3.3 & 11.8 \\
\hline Small sigmoid $(<60 \mu \mathrm{m})$ & 7.0 & 6.0 & 4.1 & 7.0 & 4.0 & 5.8 \\
\hline
\end{tabular}

\footnotetext{
* conidia with broken arms, probably $T$. elegans and $T$. chaetocladium
} 


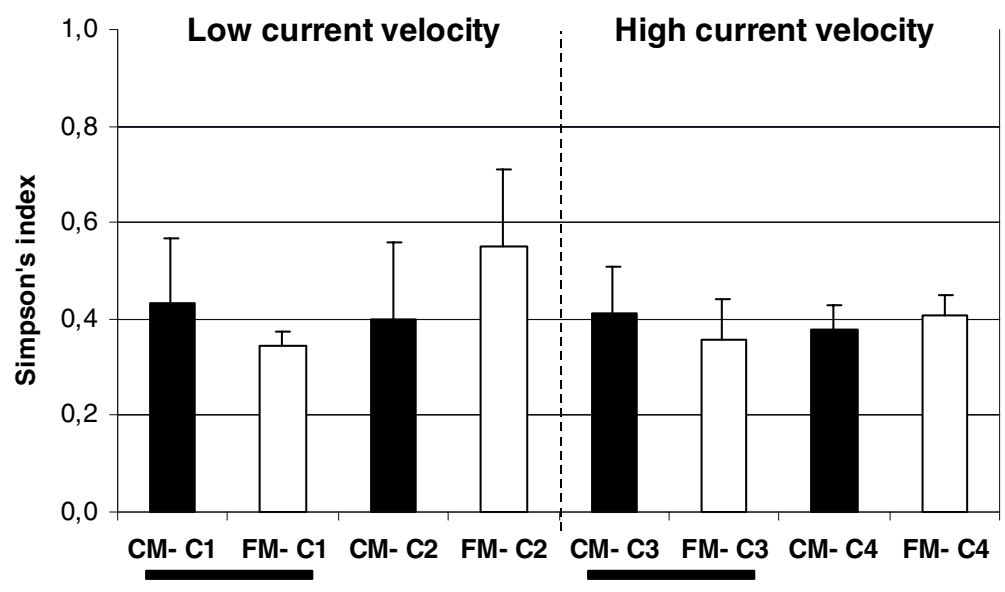

Figure 5. Simpson's index, D (mean $\pm \mathrm{SE}$ ) of the fungal assemblages colonizing alder leaves incubated in coarse mesh (CM) and fine mesh (FM) bags in channels C1, C2, C3 and C4 after 28 days. Horizontal solid bars indicate shredder presence.

found lower fungal species richness (BÄRLOCHER, 1980) and lower fungal sporulation rates (BÄRLOCHER, 1982) in coarse mesh bags but this effect of mesh size was confounded with shredder presence.

In our study there was also no effect of shredder activity on fungal parameters, and so, our results agree with those of HowE and SUBERKROPP (1994). Although invertebrates caused a significant higher mass loss in coarse mesh bags in channels with shredders than in chan-

Table 8. Results from the 4-way ANOVA (mesh type, current velocity, shredders and time as categorical variables) on the Simpson's index of the fungal assemblages colonizing alder leaves incubated in artificial channels.

\begin{tabular}{lrrrrc}
\hline & \multicolumn{1}{c}{ SS } & df & MS & F ratio & p \\
\hline Intercept & 27.195 & 1 & 27.195 & 15.970 & 0.000 \\
(1) Mesh type & 0.076 & 1 & 0.076 & 0.045 & 0.833 \\
(2) Velocity & 22.692 & 1 & 22.692 & 13.326 & 0.001 \\
(3) Shredders & 2.336 & 1 & 2.336 & 1.372 & 0.246 \\
(4) Time & 1.866 & 3 & 0.622 & 0.365 & 0.778 \\
Mesh type*Velocity & 0.010 & 1 & 0.010 & 0.006 & 0.940 \\
Mesh type*Shredders & 0.138 & 1 & 0.138 & 0.081 & 0.777 \\
Velocity*Shredders & 2.407 & 1 & 2.407 & 1.414 & 0.239 \\
Mesh type*Time & 0.848 & 3 & 0.283 & 0.166 & 0.919 \\
Velocity*Time & 1.292 & 3 & 0.431 & 0.253 & 0.859 \\
Shredders*Time & 3.333 & 3 & 1.111 & 0.652 & 0.584 \\
Mesh type*Velocity*Shredders & 0.037 & 1 & 0.037 & 0.022 & 0.883 \\
Mesh type*Velocity*Time & 0.258 & 3 & 0.086 & 0.051 & 0.985 \\
Mesh type*Shredders*Time & 0.207 & 3 & 0.069 & 0.040 & 0.989 \\
Velocity*Shredders*Time & 1.867 & 3 & 0.622 & 0.365 & 0.778 \\
$1 * 2 * 3 * 4$ & 0.131 & 3 & 0.044 & 0.026 & 0.994 \\
Error & 107.278 & 63 & 1.703 & & \\
\hline
\end{tabular}


nels without shredders, this reduction in available substrate was not translated in a reduction of the number of species colonizing it or in a reduction of the fungal sporulation and diversity. It is therefore plausible that, at least in the case of Sericostoma sp., feeding does not selectively favour some species, as there was no consistent response of fungal species to shredder presence. Nevertheless, other shredders have been reported to discriminate between leaves colonized by different fungal species, when this colonization is discrete (ARSUFFI and SUBERKROPP, 1989). However, in our study each leaf was colonized by several fungal species and it is plausible that mycelia from different species of fungi may grow so intrinsically associated that discrimination would be impossible for a large size shredder. Hence, our results disagree with those of BÄRLOCHER $(1980,1982)$ who found a negative effect of shredders feeding on the fungal assemblage structure as they acted either as predators on the early fungal colonizers or as competitors of the later fungal colonizers. In our channel system the number of fungal species that could colonize leaves was low and generally leaves became fully colonized after 14 (67\% of samples) or 21 (21\% of samples) days and so shredders were probably not competitors of fungi. Rossi (1985), on the other hand, found a positive effect of shredders on the fungal assemblage colonizing leaf detritus what was attributed to the facilitation of fungal colonization by shredders damaging leaf epidermis. In our case this facilitation effect was not observed.

Current velocity had, however, a significant effect in the fungal parameters determined, but not in the mass loss of alder leaves. Leaves exposed in high current velocity channels had higher sporulation rates, cumulative conidial production and number of fungal species and lower Simpson's index (lower heterogeneity) than leaves exposed in low current velocity channels. Since the channels system was a closed circuit and channels were not independent, the number of conidia and species that could potentially colonize leaves was the same in all four channels. Therefore, the higher sporulation rate, cumulative conidial production and number of species in high current velocity channels could only be explained by stimulation of the sporulation itself, and not of the colonization rate. We therefore conclude that turbulence is a major factor affecting the reproductive activity of aquatic hyphomycetes as previously suggested (reviewed by BÄRLOCHER, 1992). High current velocity (i.e. high turbulence) can stimulate sporulation by (a) reducing the time required for spore development, (b) increasing the number of conidiophores per unit area (BÄRLOCHER, 1992), (c) stimulating conidia detachment or (d) facilitating nutrient acquisition. However, as sporulation from all samples was induced in the same conditions (orbital shaker at $100 \mathrm{rpm}$ ), it is most plausible that high current velocity in the channels had stimulated sporulation by increasing the number of conidiophores per unit area. Nutrient acquisition by fungi was probably not different between current velocity channels as the range of current velocities tested was low.

In summary, there was no evidence that mesh type or invertebrate feeding on decaying leaves affected aquatic hyphomycetes assemblage structure. Nevertheless, in the real stream conditions it is likely to be suspended sediments that could clog fine mesh bags. On the other hand, there was higher aquatic hyphomycetes activity in channels with high current velocity when compared to channels with low current velocity, particularly due to the stimulation of certain species. Thus, in studies where the fungal assemblage structure on decomposing litter in streams is to be addressed careful should be taken regarding the current conditions where the litter is going to be emerged.

\section{Acknowledgements}

We are grateful to Dr. JoÃo L. M. P. DE LIMA for facilitating the use of laboratory flumes, Mr. JOAQUIM CORDEIRO for the assistance provided in the construction of the laboratory flumes and RICARDO GOMES for flumes schemes and current velocity measurements. Financial support was provided by the Fundação para a Ciência e Tecnologia (Programa POCTI/20/SFRH/BD/11350/2002-grant to V. FER- 
REIRA) and the European Union (contract number EVK1-2001-00088). The suggestions by two anonymous reviewers greatly improved the manuscript.

\section{References}

APHA, 1995: Standard methods for the examination of water and wastewater, $19^{\text {th }}$ ed. EATON, A. E., L. S. Clesceri and A. E. Greenberg (eds.), Washington D.C.

Arsuffi, T. L. and K. Suberkropp, 1985: Selective feeding by stream caddisfly (Trichoptera) detritivoros on leaves with fungal-colonized patches. - Oikos 45: 50-58.

ARsuffi, T. L. and K. Suberkropp, 1986: Growth of two stream caddisflies (Trichoptera) on leaves colonized by different fungal species. - J. N. Am. Benthol. Soc. 5: 297-305.

ARsufFI, T. L. and K. SubERKROPP, 1988: Effects of fungal mycelia and enzymatically degraded leaves on feeding and performance of caddisfly (Trichoptera) larvae. - J. N. Am. Benthol. Soc. 7: 205-211.

Arsuffi, T. L. and K. SubERKROPP, 1989: Selective feeding by shredders on leaf-colonizing stream fungi: comparison of macroinvertebrate taxa. - Oecologia 79: 30-37.

BÄRLOCHER, F. and B. KENDRICK, 1975: Leaf-conditioning by microorganisms. - Oecologia 20: $359-362$.

BÄRLOCHER, F., 1980: Leaf-eating invertebrates as competitors of aquatic hyphomycetes. - Oecologia 47: 303-306.

BÄRLOCHER, F., 1982: Conidium production from leaves and needles in four streams. - Can. J. Bot. 60: $1487-1494$.

BÄRLOCHER, F., 1992: Research on aquatic hyphomycetes: historical background and overview. - In: BÄrLOCHER, F. (ed.). The ecology of aquatic hyphomycetes. Springer-Verlag, Berlin Heidelberg. pp. $1-15$.

Chauvet, E., 1992: De la biologie des hyphomycetes aquatiques à l'écologie des rivières. - Cryptogamie, Mycol. 13: 203-214.

Cuffney, T. F., J. B. Wallace and G. J. Lugthart, 1990: Experimental evidence quantifying the role of benthic invertebrates in organic matter dynamics of headwater streams. - Freshw. Biol. 23: $281-299$.

Ferreira V., M. A. S. GraçA, J. L. M. P. De Lima and R. Gomes. 2006: Role of physical fragmentation and invertebrate activity in the breakdown rate of leaves. - Arch. Hydrobiol. in press.

GeSSNER, M. O. and E. CHAUVET, 1994: Importance of stream microfungi in controlling breakdown rates of leaf litter. - Ecology 75: 1807-1817.

Gessner, M. O., E. Chauvet and M. Dobson, 1999: A perspective on leaf litter breakdown in streams. - Oikos 85: 377-383.

Graça, M. A. S., C. Cressa, M. O. Gessner, M. J. Feio, K. A. Callies and C. Barrios, 2001: Food quality, feeding preferences, survival and growth of shredders from temperate and tropical streams. - Freshw. Biol. 46: 947-957.

GraçA, M. A. S., S. Y. NEwEll and R. T. KNEIB, 2002: Grazing rates of organic matter and living fungal biomass of decaying Spartina alterniflora by three species of salt-march invertebrates. - Mar. Biol. 136: 281-289.

Hieber, M. and M. O. Gessner, 2002: Contribution of stream detritivores, fungi, and bacteria to leaf breakdown based on biomass estimates. - Ecology 83: 1026-1038.

Howe, M. J. and K. SuberKROPP, 1994: Effects of isopod (Lirceus sp.) feeding on aquatic hyphomycetes colonizing leaves in a stream. - Arch. Hydrobiol. 130: 93-103.

Pozo, J., E. Gonzáles, J. R. Díez, J. Molinero and A. Elósegui, 1997: Inputs of particulate organic matter to streams with different riparian vegetation. - J. N. Am. Benthol. Soc. 16: 602-611.

Rossi, L., 1985: Interactions between invertebrates and microfungi in freshwater ecosystems. - Oikos 44: $175-184$.

Sabetta, L., M. L. Costantini, O. Maggi, A. M. Persiani and L. Rossi, 2000: Interactions between detritívoros and microfungi during the leaf detritus decomposition in a volcanic lake (Lake Vico- central Italy). - Hydrobiol. 439: 49-60.

StEWART, B. A., 1992: The effect of invertebrates on leaf decomposition rates in two small woodland streams in southern Africa. - Arch. Hydrobiol. 124: 19-33.

SuBERKROPP, K. and M. J. KLUG, 1976: Fungi and bacteria associated with leaves during processing in a woodland stream. - Ecology 57: 707-719. 
Suberkropp, K. and J. B. Wallace, 1992: Aquatic hyphomycetes in insecticide-treated and untreated streams. - J. N. Am. Benthol. Soc. 11: 165-171

SubERKROPP, K., 2003: Methods for examining interactions between freshwater fungi and macroinvertebrates. - Fungal Div. Res. Se. 10: 159-171.

Vannote, R. L., G. W. Minshal, K. W. Cummins, J. R. Sedall and C. E. Cushing, 1980: The river continuum concept. - Can. J. Fish. Aquat. Sci. 37: 130-137.

WASHington, H. G., 1984: Diversity, biotic and similarity indices. A review with special relevance to aquatic ecosystems. - Water Res. 18: 653-694.

ZAR, J. H., 1999: Biostatistical analysis. - Prentice-Hall International, Inc. USA.

Manuscript received October 18th, 2005; revised November 29th, 2005; accepted December 7th, 2005 